\title{
ANALÝZA ÚROVNE INOVÁCIÍ POŠTOVÝCH SLUŽIEB VYBRANÝCH POŠTOVÝCH OPERÁTOROV
}

\author{
Bystrík Nemček $^{1}$, Iveta Kremeňová ${ }^{2}$ Rita Tornyaiová $^{3}$
}

Úvod

Národný poštový operátor - Slovenská pošta, a.s. musí v súčasnosti pružne reagovat' na meniace sa podmienky v rámci plne liberalizovaného trhu. Hlavným z dôvodov je fakt, že pri zachovaní konkurencieschopnosti sa musí uberat' cestou inovácií. Okrem liberalizácie a s ňou súvisiace otvorenie poštového trhu majú vel'ký význam aj informačno-komunikačné technológie a elektronizácia, ktoré ovplyvňujú dennodenne život nás všetkých. V podmienkach globálneho trhu je inovácia a inovačná schopnost' dôležitá aj v súvislosti s narastajúcimi požiadavkami zákazníkov, výkonnejšou konkurenciou, technologickým rozvojom, a preto by mala byt' realizácia inovácií prostriedkom na prispôsobenie sa týmto zmenám.

\section{Inovácie}

„Je treba odbúrat' všetko, čo zastaralo, čo sa opotrebovalo, čo je prežitkom a obohacovat' ekonomický proces o nové, mladé rozvojové faktory - nové výrobky, nové technológie, novú organizáciu práce, nových odborníkov“...

Jozef Schumpeter, otec inovácií (1883-1950)

V roku 1911 sa Jozef Schumpeter postaral o dôležitú zmenu v chápaní realizácie zmien, kedy naformuloval tzv. „kombinácie vývojových zmien", chápané ako prekračovanie obnovovania systémov a procesov v uzavretom kruhu. Špecifikoval pät' základných zmien:

- používanie novej techniky, výrobných procesov a marketingového zabezpečenia výroby,

- zavedenie nových produktov, resp. pôvodných produktov s novými vlastnost'ami,

- používanie nových surovín a materiálov,

- zmeny v organizácii výroby, distribúcie, predaja,

- otváranie nových trhov, zmeny štruktúry trhu.

\footnotetext{
${ }^{1}$ Ing. Bystrík Nemček., Žilinská univerzita v Žiline, Fakulta Prevádzky a ekonomiky dopravy a spojov, Katedra spojov, Univerzitná 1, 01026 Žilina, tel.: +4215133144, fax: +4215655615, e-mail: bystrik.nemcek@fpedas.uniza.sk

${ }^{2}$ Doc. Ing. Iveta Kremeňová, PhD., Žilinská univerzita v Žiline, Fakulta Prevádzky a ekonomiky dopravy a spojov, Katedra spojov, Univerzitná 1, 01026 Žilina, tel.: +4215133100, fax: +4215655615, e-mail: iveta.kremenova@fpedas.uniza.sk

${ }^{3}$ Ing. Rita Tornyaiová., Žilinská univerzita v Žiline, externá doktorandka na Katedre spojov, Fakulta Prevádzky a ekonomiky dopravy a spojov, Univerzitná 1, 01026 Žilina, tel.: +4215133101, fax: +4215655615,
} 
V roku 1935 zaviedol pre túto oblast' nový pojem "inovácia", definovanú ako "zmenu s ciel'om využivat' nové druhy spotrebného tovaru, nových výrobných a dopravných prostriedkov, nových trhov a foriem organizácie výroby a poskytovania služieb".

Ďalšie definície inovácií si môžeme priblížit’ nasledovne podl’a rôznych autorov:

\section{Crawford:}

„Zmeny v priemysle, najmä v technologickom rozvoji a ich aplikácie vo výrobkoch, výrobných procesoch a službách sa označujú spoločným pojmom inovácie““

Základnými prvkami priemyselných inovácií sú:

- základné poznatky a know-how

- idey, ktoré transformujú základné poznatky do nových výrobkov, procesov a služieb

- vysoká rýchlost' implementácie ideí na trhové podmienky

Valenta:

„Inovácia vyjadruje zmenu v pôvodnej štruktúre výrobného organizmu t.j. prechod k novému stavu vnútornej štruktúry. Do inovácie patria zmeny výrobkov, technológii, výrobných prostriedkov, štruktúry, organizácie a trhu. Zmeny môžu byt' kvantitatívne a kvalitatívne.“

\section{Cooper:}

„Inovácia zahrňuje použitie poznatkov na generovanie a praktickú aplikáciu novej idei, prinášajúcej prospech.

\section{Analýza inovácií služieb jednotlivých poštových operátorov}

V d’alších častiach článku sa venujeme vybraným poštovým operátorom a ich najzaujímavejším inováciám služieb.

V súčasnej dobe sa Slovenská pošta, a.s. (SP) začala venovat' projektu, zameranému na inováciu vybraných služieb a implementáciu nových e-služieb v oblasti e-governmentu. Je to nový projekt, ktorým pošta rozširuje svoje služby, a zároveň sprístupní služby štátu (egovernment) občanom prostredníctvom pobočkovej siete. Zákazník si tak pod jednou strechou na pošte bude môct' vybavit' všetky najčastejšie používané služby štátu. Do konca roka 2012 bude pošta poskytovat' tieto služby na 100 poštách. V budúcom roku plánuje počet pracovísk rozšírit' na 400 a v roku 2014 by nové služby štátnej a verejnej správy chcela občanom sprístupnit' až na 800 poštách. Hlavným benefitom Integrovaných obslužných miest je, že služby sú elektronické a sú poskytované z jedného miesta.[1]

Integrované obslužné miesto (IOM) je kontaktné miesto na vybavovanie úradných záležitostí. Je určené občanom, ktorí uprednostňujú osobnú komunikáciu s verejnou správou alebo požadujú asistované sprístupnenie elektronických služieb. Slovenská pošta, a.s. označuje svoje pracoviská vlastným obchodným označením e.SO (elektronické služby obyvatel'stvu). O službu môže zákazník požiadat' na základe žiadosti vytvorenej priamo na pracovisku e.SO. Na základe žiadosti dostane výstup v listinnej podobe, ktorý je opatrený osvedčovacou doložkou. Takýto dokument je použitel'ný na právne účely.

V súčasnosti ponúka Integrované obslužné miesto nasledujúce služby:

- asistované služby - výpis z obchodného registra na právne účely,

- d'alšie služby:

- overenie originality elektronického čipu Osvedčenia o evidencii vozidla (OoEV I.),

- overenie originality elektronického čipu a odpis elektronických údajov z OoEV I.

Overenie originality elektronického čipu je možné vykonat' zo slovenských a rakúskych osvedčení o evidencii vozidla. Aktuálne je možné využit’ služby na 12 poštách: 
Banská Bystrica 8, Bratislava 4, Bratislava 216, Komárno 1, Košice 19, Liptovský Mikuláš 1, Lučenec 1, Nitra 3, Poprad 2, Prešov 10, Trenčín 1, Žilina 2. [2]

Okrem úspešného spustenia nového projektu zameraného na sprístupnenie služieb štátu občanom (e-government), SP zaviedla nové elektronické služby. Medzi tieto služby patria:

- ePodací hárok,

- Elektronická podatel’ňa,

- eSIPO:

- eSIPO pre firmy,

- eSIPO pre občanov,

- e-Dokument. [3]

V nasledovnej časti článku sme analyzovali aké nové služby ponúkajú zahraniční národní poštoví operátori. Na analýzu nových služieb na poštovom trhu v zahraničí sme si vybrali národných poštových operátorov z nasledovných krajín: Česká republika, Pol'sko, Kanada, Francúzsko a Rakúsko.

Národný poštový operátor Česká pošta, š.p. rozšírila svoje balíkové portfólio o tieto štyri nové produkty: "Balíky na poštu", "Balíky do ruky", "Balíky expres" a "Balíky nadrozměr". Tieto zmeny súvisia so zostrujúcim sa konkurenčným bojom a celkovým rastom trhu v dôsledku rozvoja on-line nakupovania. [4]

„Balík nadrozměr“ je služba, ktorá prepraví zásielky o hmotnosti až 1000 kg. Zmluvným zákazníkom umožňujeme prepravu paletovaných a nepaletovaných zásielok po celej Českej republike. Nasledujúci pracovný deň po vyzdvihnutí zásielky Českou poštou, š.p. bude adresát kontaktovaný pracovníkom na telefónnom čísle, ktoré zákazník uviedol pri vybraní zásielky a dohodne sa s ním na najvhodnejšom termíne doručenia. Zásielku, ktorú chce zákazník poslat' a ktorá splńa parametre „Balík nadrozměr“, Česká pošta, š.p. vyzdvihne bud’ priamo v prevádzke zákazníka alebo na dohodnutom mieste a dopraví danú zásielku adresátovi na určené miesto.

Benefity k službe „Balík nadrozměr“ sú:

- služba pre zásielky do 1000 kg,

- preprava zásielok "od dverí k dverám",

- telefonická dohoda termínu doručenia priamo s adresátom,

- V cene služby už poistenie do hodnoty 50.000 Kč (v prepočte približne 2020.202 €).[5]

„Balík do ruky“ je vnútroštátna preprava balíkov do hmotnosti $30 \mathrm{~kg}$ po celej Českej republike. Garancia doručenia priamo do rúk adresáta už nasledujúci pracovný deň. Podanie balíku je možné na vybraných poštách. Výhodou tohto balíka je, že si adresát môže upravit' čas alebo spôsob doručenia. Vo vybraných lokalitách ponúka Česká pošta vol'bu popoludňajšieho doručovanie. Možnost' garantovaného času dodania do 10./12./14. hodiny alebo v sobotu. Adresáta informujeme o doručovaní balíku prostredníctvom SMS alebo emailom už $\mathrm{v}$ deň podania a neustále $\mathrm{s}$ ním Česká pošta komunikujeme. Ak uprednostňuje adresát osobné vyzdvihnutie balíku, je tu možnost' uloženia na pošte. Udaná cena balíka do hodnoty 50000 Kč (2020.202 €) je zahrnutá už v základnej cene služby. Odosielatel' si na základe zmluvy môže objednat' zvoz a nemusí íst' na poštu. [6] 
„Balík na poštu“ je služba pre prepravu vnútroštátnych balíkov do hmotnosti 30 kg po celej Českej republike. Odosielatel' alebo adresát si volí poštu, na ktorej bude balík pripravený na vyzdvihnutie. Garancia možnosti vyzdvihnutia na zvolené pošte už nasledujúci pracovný deň. Možnost' podania balíka je na väčšine pôšt. Avizovanie je neoddelitel'nou súčast'ou služby. Výhoda služby „Balík na poštu“ spočíva tom, že zákazník nemusí byt' v určitý čas na určitom mieste, balík si môže vyzdvihnút' na zvolenej pošte a v čase, kedy sa mu to hodí. Prostredníctvom nástroja umiestneného na e-shopoch alebo na webovej stránke Českej pošty, š.p. si jednoducho vyberie poštu, na ktorú má byt' balík dodaný. Adresáta informujeme o možnostiach vyzdvihnutia prostredníctvom SMS alebo e-mailom už v deň podania a znovu v čase uloženia balíka na pošte. Udaná cena balíka do hodnoty 50000 Kč (2020.202 €) je zahrnutá už v základnej cene služby. Odosielatel' si na základe zmluvy môže objednat' zvoz a nemusí na poštu. [7]

„Balík Expres“ je služba České pošty pre expresné zásielky do 15 kg, ktoré sú doručené už v deň ich podania.

Služba je ponúkaná pre:

- zásielky podané v Prahe a adresované do krajských miest,

- zásielky podané v krajských mestách a adresované do Prahy,

- zásielky podané v Prahe a adresované do Prahy,

- zásielky podané v krajskom meste a adresované do toho istého krajského mesta. [8]

Medzi d’alšiu novú službu, ktorú Česká pošta, š.p. ponúka, patrí „MMS pohlednice“. Táto služba umožňuje obrázok a text zo zákazníkovho mobilného telefónu vytlačit' a zaslat' na l’ubovol'nú adresu v rámci Českej republiky. Zákazník odošle MMS s obrázkom a textom v tvare MENO PRIEZVISKO*ULICA Č.P.*MESTO*PSČ*TEXT na zadané telefónne číslo alebo pomocou formulára na web stránke Českej pošty. Obratom zákazník dostane SMS s potvrdením prijatia MMS s výzvou k platbe. Na prijatú správu zákazník odpovie, a tým potvrdí platbu pomocou SMS správy. Nakoniec dostane potvrdzovaciu SMS správu s informáciou o tom, že jeho pohl'adnica bola odovzdaná k vytlačeniu a odoslaniu. Za jeden až dva dni bude pohl'adnica doručená na zadanú adresu prijímatel'a. [9]

Národný poštový operátor Kanadská pošta zaviedla nový interaktívny softvérový nástroj, ktorý je predovšetkým určený pre stredné a malé firmy. Nový interaktívny softvérový nástroj tak pomôže malým a stredným firmám efektívnejšie ponúkat' ich služby. V piatich krokoch majú možnost' jednoduchým spôsobom definovat' ale aj zadat' svoju marketingovú kampaň prostredníctvom neadresných zásielok. Tento moderný nástroj vychádza z možností Kanadskej pošty, ktorá má k dispozícii kompletnú databázu adries s dátami zo sčítania l’udu. K dispozícii má aj d’alšie demografické údaje, ako sú napr. príjmy domácností, vzdelanie, vek a rodinný stav. No a samozrejme ak k tomu pripočítame, že Kanadská pošta ma prístup ku každej domovej schránke, ide skutočne o unikátny direct marketingový nástroj.

\section{kroky:}

Zákazník jednoducho cez webový portál Kanadskej pošty absolvuje nasledujúce

- Popis kampane - tu napr. špecifikuje samotný charakter zásielok (vel'kost'), termín distribúcie, špecifikácia doručovania - domy, farmy, byty, firmy. V tejto fáze môže zákazník špecifikovat' tiež svoje možnosti rozpočtu. 
- Výber ciel'ovej skupiny - na tomto mieste si zákazník zo 7 demografických premenných môže vybrat' 3 a tak bližšie špecifikovat' ciel'ovú skupinu napr. podl'a miesta bývania (mesto, vidiek) príjmov, veku, vzdelania.

- Hlavná oblast' distribúcie - zákazník v tret’om kroku špecifikuje lokalitu (región) kam by chcel smerovat' svoju ponuku. Môže to zrealizovat' interaktívne priamo na mape alebo pomocou d'alších filtrov (vzdialenost', čas jazdy, rádius a pod.).

- Kontrola návrhu - ide vlastne o rekapituláciu doterajšej špecifikácie. Na tomto mieste zákazník uvidí kol'ko zásielok jeho špecifikácia vygenerovala, aké budú celkové náklady na kampaň. Zákazník si môže tento návrh uložit' alebo pristúpit' $\mathrm{k}$ záverečnému kroku - objednávke.

- Objednávka - Ak zákazníkovi vyhovuje definované zadanie, na tomto mieste môže Kanadskej pošte zadat' svoju objednávku. [10]

Národný poštový operátor Francúzka pošta rozšírila svoje listové produktové portfólio o ekonomický a elektronický list. Elektronický list je služba, prostredníctvom ktorej si zákazník na internetovej stránke národného poštového operátora priamo pomocou aplikácie vytvorí list, ktorý následne elektronicky odošle poštovému národnému operátorovi. Zákazník sa zaregistruje a pri využití služby si len vyberie vytvorený dokument (napr. v MS Word), tento dokument je následne „stiahnutý“ do aplikácie, pričom je automaticky extrahovaná adresa adresáta (ak je v liste uvedená) a zákazník po verifikácii údajov obsahu zásielky a adresy si môže zvolit’ či zásielku chce tlačit' farebne alebo čierno-bielo, obojstranne alebo jednostranne. Zákazník má možnost' do obálky vložit' aj viacero rovnakých alebo rôznych listov a má k dispozícii evidenciu a aj náhl’ady všetkých odoslaných zásielok. Zákazníci majú možnost' zistit' na webovej stránke presnú cenu elektronického listu pomocou kalkulátora ceny. Dôvernost' pri výrobnom procese, t. j. tlač a obálkovanie je zabezpečená registráciou zákazníka. Elektronický list je možné zaplatit’ on-line. [11]

Na zvýšenie úspešnosti doručenia poštovej zásielky adresátovi v prípade, že nie je momentálne zastihnutel'ný, majú slúžit' odkladacie boxy. Tieto boxy sú ponúkané Rakúskou poštou. Ide o špeciálny box, do ktorého doručovatel' odloží balík alebo list väčších rozmerov, v prípade ak adresát nie je momentálne zastihnutel'ný. Do odkladacieho boxu doručovatel' uloží poštovú zásielku a do poštovej schránky adresátovi vhodí oznámenie o uložení poštovej zásielky. Ide o špecifické oznámenie v podobe plastovej karty so zabudovaným čipom. Adresát túto plastovú kartu priloží k určenému miestu na špeciálnom boxe a tým tento box otvorí. Po vybratí balíka do schránky vloží kartu a zavrie dvierka boxu. Špeciálny odkladací box ponúka Rakúska pošta a podl'a nej má možnost' adresát týmto spôsobom prebrat' až 95 \% všetkých jemu adresovaných zásielok. [12]

Rakúska pošta v súčasnosti rozbieha nový projekt, ktorého hlavným ciel’om je doručovanie zásielok $\mathrm{s}$ využitím mobilných technológií. Rakúska pošta odštartovala dva pilotné projekty zamerané na zvýšenie úspešnosti doručenia zásielok. Prvý projekt s názvom „Aviso SMS“ rozbieha Rakúska pošta v skúšobnej verzii v častiach Viedne a Linzu. Podstata služby spočíva $\mathrm{v}$ tom, že prijímatelia balíkov obdržia SMS o tom, že ich zásielky boli doručovatel'om uložené na príslušnej pošte. Súčasne sa rozbieha aj d’alší pilotný projekt. Doručovatelia budú vybavený vlastným mobilným telefónom, ktorý im umožní kontaktovat' prijímatel'a zásielky v prípade, že ho nezastihne pri doručení. Má tak možnost' definovat' si alternatívny spôsob dodania zásielky. [13] 


\section{Záver}

Nevyhnutným predpokladom úspešnosti poštových operátorov je neustály proces realizácie inovácií v oblasti poštových služieb. Poštoví operátorovi by mali pokračovat' $\mathrm{v}$ nastolenom trende $\mathrm{v}$ oblasti informačno-komunikačných technológií a systematicky implementovat' nové zmeny $\mathrm{v}$ rámci produktového portfólia. Analýzou jednotlivých poštových trhov bolo zistené, že poštoví operátori zareagovali na nové možnosti súvisiace s elektronizáciou, avšak otázkou zostáva v akom rozsahu. Medzi jednotlivými poštovými podnikmi vznikajú rozdiely v súvislosti s implementáciou nových služieb resp. inováciou existujúcich služieb.

\section{Literatúra}

[1] ČAJKOVÁ, L.: Inovácia poštových služieb ako reakcia na výskum uskutočnený v rámci NUTS 2 Stredné Slovensko: diplomová práca. Žilina: 2012, 89s.

[2] Bela Lisáková. Slovenská pošta otvorila prvé Integrované obslužné miesto, poskytne výpis z obchodného registra či overenie vozidla. [online]. [cit. 2012-10-15].Dostupné na internete: <http://tlacovespravy.wordpress.com/2012/03/06/slovenska-postaotvorila-prve- integrovane-obsluzne-miesto-poskytne-vypis-z-obchodneho-registra-cioverenie-vozidla/>.

[3] Služby integrovaných oblsužných miest. [online]. [cit. 2012-10-16]. Dostupné na internete: <http://www.posta.sk/sluzby/sluzby-integrovanych-obsluznych-miest>.

[4] Balikková revolúcia Českej pošty. [online]. [cit. 2012-10-10]. Dostupné na internete: $<$ http://www.postovesluzby.sk/zo-sveta/129/balikova-revolucia-ceskej-posty/>.

[5] Balík Nadrozměr. [online]. [cit. 2012-10-10]. Dostupné na internete: <http://www.ceskaposta.cz/cz/sluzby/baliky/cr/balik-nadrozmer-id33985/>.

[6] Balík do ruky. [online]. [cit. 2012-10-18]. Dostupné na internete: <http://www.ceskaposta.cz/cz/sluzby/baliky/cr/balik-do-ruky-id36476/>.

[7] Balík na poštu. [online]. [cit. 2012-10-17]. Dostupné na internete: <http://www.ceskaposta.cz/cz/sluzby/baliky/cr/balik-na-postu-id36477/>.

[8] Balík expres. [online]. [cit. 2012-10-12]. Dostupné na internete: <http://www.ceskaposta.cz/cz/sluzby/baliky/cr/balik-expres-id33983/>.

[9] MMS pohlednice. [online]. [cit. 2012-10-13]. Dostupné na internete: $<$ http://www.ceskaposta.cz/cz/sluzby/e-sluzby/pohlednice-mms-id286/>.

[10] Kanadská pošta pomáha SME klientom Lepšie cielit' ich propagáciu. [online]. [cit.2012-04-01].Dostupné na internete: < http://www.postovesluzby.sk/zosveta/178/kanadska-posta-pomaha-sme-klientom-lepsie-cielit-ich-propagaciu/>.

[11] Lettre en ligne. [online]. [cit. 2012-10-13]. Dostupné na internete: $<$ http://www.laposte.fr/Particulier/Envoyer-et-recevoir-du-courrier/Toutes-lesoffres/Vers-la-France/Lettre-en-ligne>.

[12] Rakúska pošta ponúka službu odkladacích boxov. [online]. [cit. 2012-10-10]. Dostupné na internete: <http://www.postovesluzby.sk/zo-sveta/165/rakuska-postaponuka-sluzbu-odkladacich-boxov/>. 
[13] Doručovanie zásielok s využitím mobilných technológií. [online]. [cit. 2012-10-14]. Dostupné na internete: <http://www.postovesluzby.sk/zo-sveta/118/dorucovaniezasielok-s-vyuzitim-mobilnych-technologii/>.

\section{Grantová podpora}

Príspevok vznikol za podpory nasledovných grantových projektov: VEGA 1/0199/11Výskum interoperability metód riadenia so strategickým zámerom organizácie a KEGA 052ŽU-4/2012 On-line riadenie výučby v procese vzdelávania voblasti informačnokomunikačných technológií. 